\title{
Politeness Performance Communications National Political Figures Prabowo
}

\author{
Siswanto ${ }^{1}$, Ermanto ${ }^{2}$, Juita $\mathbf{N}^{3}$ \\ \{cizwanto@gmail.com_-, ermanto@fbs.unp.ac.id ${ }^{2}$, Noviajuita@ymail.com³ \\ 1,2,3Universitas Negeri Padang, Jl. Hamka Air Tawar Padang Sumatera Barat 25131, \\ Indonesia
}

\begin{abstract}
Political figures is a public figure who must pay attention to the use of good language, with regard to principles of politeness and other elements. The purpose of this study was to describe the use of the principle of linguistic politeness national political figure Prabowo. The data in this study a speech utterances of six national political figure Prabowo. The method used in this research is descriptive qualitative. Technical analysis of these data is the identification of data, data classification, inteprestasi data and drawing conclusions.The results of the analysis of utterances national political figures contained Prabowo keep and violates the maxim and the two maxims of politeness principle. Speech that adhere to the maxim of politeness principle, namely: the maxim of wisdom as much as $15.46 \%$, the maxim of generosity as much as $4.12 \%, 3.09 \%$ praise maxims, maxims of humility as much as $8.24 \%$, the maxim of the deal as much as $15.46 \%$, and maxim of sympathy as much as $4.12, \%$. Speech that adhere to the two maxims of politeness principle, namely: the generosity maxim pijian as much as $2.06 \%$, the generosity with humility as much as $1.03 \%$, the generosity of the deal as much as $2.06 \%$, generosity and sympathy as much as $2.06 \%$, humility with sympathy as much as $1.03 \%$ and the agreement with sympathy as much as $1.03 \%$. Speech that violates the maxim of politeness principle, namely: the maxim of generosity as much as $2.06 \%$, maxim praise as much as $1.03 \%$, the maxim of humility as much as $1.03 \%$, the maxim of the deal as much as $19.58 \%$, and the maxim of sympathy as much as $9.28 \%$. Utterances that violate the two maxims of politeness principle, namely: the maxim of wisdom with sympathy as much as $1.03 \%$, the praise with humility as much as $2.06 \%$ and kesepakatang with sympathy as much as $3.09 \%$. That is, the speech of national political figures more dominant Prabowo adhere to the principle of politeness, of 97 data adhere to as much as 57 utterances $(58.72 \%)$ and in violation of 40 utterances $(41.28 \%)$. These results indicate the use of communication politeness principle national political figure Prabowo included in the language of assessment criteria of "good enough".
\end{abstract}

Keywords:Politeness principle, communication, and national political figures.

\section{Introduction}

Politeness language is a term associated with courtesy, respect, good attitude or behavior that is inappropriate. In everyday life, the relationship decency and fair play suggests that politeness is not only related to language, melaikan Jugan with nonverbal behavior. Manners in the form of speech or politeness at least not solely the primary motivation for speakers to speak, but also a factor that is keeping up with the correct regulator, fun and not in vain [1].

Politeness national political leaders in Indonesia to the attention of the researchers. First,[2] concluded that the strategy of President Jokowi in instilling linguistic ideology and manifesto of government is done by utilizing the formal aspects of the text of his speech. Second,[3] concluded that political communicator using YouTube as alternative media to form a positive image and influence public opinion. Third,[4] states that a polite greeting may facilitate the planting of ideology. Fourth, [5] The findings of the research is the use of the 
principle of modesty officials of West Sumatra according to the maxims of wisdom, generosity maxims, maxims of praise, humility humility maxims, maxims agreement and sympathy maxim.

Violations of politeness in speaking of the last decade seems to be a serious phenomenon in the world of politics. The study, discuss it among them in England [6],[7],[8]; in the USA [9],[10],[11]; and in France [12]. Research in Indonesia about it shows that the language in the political world almost lost its meaning because it is a means of blaming, berate, attack, even dropping other people or political opponents [13]. It is also evident from several studies in Persian [14]; in Japan [15],[16],[17]; in Turkey [18]; and in Italy [19].

Political communication means talking to people associated with what is to be achieved in the context of the elections, is associated with intelligence and logic to discuss a problem state, vision, mission, plan, program and arguments. The situation is, consciously or unconsciously the political elite has been conducting activities to speak with the position as speaker and hearer. Speakers as people who speak, those who declare certain pragmatic function in the event of communication.

National political leaders must pay attention to two things and other elements. Prabowo is a political figure of concern to the general public due to ketokohannya in political attitudes. Prabowo verbal communication becomes the most important thing to note, if the use of the principle of politeness are not addressed, will cause a reaction that is worrying for society, the impacts can include verbal abuse or physical violence. It is encouraging to examine the activities of language in political communication Prabowo, who is a political figure. Lt. Gen. (ret) Prabowo Djojohadikusomo, who was born in Jakarta, 17 October 1951, who currently serves as the chairman of the Great Indonesia Movement Party, other than that Prabowo Djojohadikusomo was a military officer and businessman. After listening to references in the form of research beforehand, investigators have not yet found the object of research with studies and research alike. It shows that the performance of politeness Prabowo political communication needs to be studied.

The principle of modesty can be translated into six maxims, namely (1) the maxim of wisdom, (2) mercy maxim, (3) acceptance, (4) humility, (5) agreements, (6) sympathy. Politeness is acceptable with respect to, the correct behavior, shows that is not limited to language, but also can include nonverbal behavior and nonlinguistic. Brown and Levinson (1987, p.229-232), explains that the considerations that form the basis of politeness strategy selection factors are (1) the social distance between the speaker and the hearer (social distance), (2) the difference of power between speakers (speakers) and speakers (addreas power), (3) the relative status of speech acts. In certain cultures there are certain forms of speech that are considered polite and some forms of speech that are not considered polite.[20].

The purpose of this study is describes the use of the principle of oral communication kesantuna national political figure Prabowo.In this study, researchers analyzed the use of verbal politeness principle komuinikasi national political figure Prabowo. Researchers also analyzed breach of oral communication politeness national political figure Prabowo.

\section{Methods}

The method used in this research is qualitative method because it does not prioritize the figures, but describe with words. This study uses language research. Research related languages with the aim of a study involving the collection and selection of data [21] .. language study method used in this study because it is the most appropriate research methods 
to the phenomena that have been proposed. The research is a qualitative descriptive for the presentation of the data obtained based on the object of research.

\section{Results and discussion}

This research data in the form of oral speech uttered by a national political figure Prabowo in speech activity. Transcribed speech to forms of written language to facilitate data analysis. Data downloaded from youtube account Gerindra Tv.

\subsection{Results}

This study was done using theory Lecch which outlines six maxims: (1) perinsip politeness, (a) the maxim of wisdom, (b) maxim generosity, (c) maxim awards, (d) the maxim of humility, (e) the maxim of the agreement, (f) the maxim of sympathy. From the analysis of the speech can be classified using politeness principle Prabwo Subianto national political figures in the following table.

Table 1. Use of Politeness Principles National Political Figures Prabowo.

\begin{tabular}{|c|c|c|c|c|}
\hline Number & Politeness principle & & $\begin{array}{c}\text { number of } \\
\text { speech }\end{array}$ & Percentage \\
\hline \multirow[t]{12}{*}{1} & adhere to the maxim & & 57 & $58.72 \%$ \\
\hline & a. Wisdom & & 15 & $15.46 \%$ \\
\hline & b. Generosity & & 4 & $4.12 \%$ \\
\hline & c. Praise & & 3 & $3.09 \%$ \\
\hline & d. Modesty & & 8 & $8.24 \%$ \\
\hline & e. Deal & & 15 & $15.46 \%$ \\
\hline & f. Sympathy & & 4 & $4.12 \%$ \\
\hline & g. Generosity and Praise & & 2 & $2.06 \%$ \\
\hline & h. Generosity and Humility & & 1 & $1.03 \%$ \\
\hline & i. Generosity and Agreements & & 2 & $2.06 \%$ \\
\hline & j. Generosity and sympathy & & 2 & $2.06 \%$ \\
\hline & k. Humility and sympathy & & 1 & $1.03 \%$ \\
\hline \multirow[t]{10}{*}{2} & violates the maxim & & 40 & $41.28 \%$ \\
\hline & a. Generosity & & 2 & $2.06 \%$ \\
\hline & b. Praise & & 1 & $1.03 \%$ \\
\hline & c. Modesty & & 3 & $3.09 \%$ \\
\hline & d. Deal & & 19 & $19.58 \%$ \\
\hline & e. Sympathy & & 9 & $9.27 \%$ \\
\hline & f. Wisdom and sympathy & & 1 & $1.03 \%$ \\
\hline & g. Praise and Kerendaha Heart & & 2 & 2.06 \\
\hline & h. Agreements and Sympathy & & 3 & 3.09 \\
\hline & & total & 97 & $100 \%$ \\
\hline
\end{tabular}

The result of this research is a national political figure Prabowo there abide and violating the maxim, two maxims, maxims and four maxims three working principles. Speech Prabowo national political figures are memetahui one maxim of the principles of cooperation, namely: the maxim of quantity as much as $1.03 \%$. National political figures of speech that adhere to two principles of cooperation, namely: abide Masim quantity with as much relevance $3.09 \%$, and adhere to the maxim of relevance to the maxim of how much $1.03 \%$, Utterances national 
political figure Prabowo three maxims that comply with the principles of cooperation, namely: the quantity, quality and relevance as $34.02 \%$, Quality, relevance and how much $2.06 \%$, as well as the quantity, relevance and how much $4.12 \%$, Speech Prabowo national political figures are also adhere to the four maxims are: maxim of quantity, maxim of quality, relevance and maxims maskism how much $7.21 \%$, Utterances national political figure Prabowo also a speech that violates the maxim of the principles of cooperation, namely: violate the maxim of quantity as much as $14.43 \%$ and the maxim of quality as much as $3.09 \%$, Utterances national political figure Prabowo two maxims that violate the principles of cooperation, namely: the maxim of quality with quantity as much as $8.24 \%$, Maxim of quantity with the maxim of relevance as $3.09 \%$, maxim of quality with the maxim of how much $3.09 \%$, And the maxim of quality with as much relevance $1.03 \%$. Utterances national political figure Prabowo three maxims that violate the principles of cooperation, namely: quantity, relevance and how much $4.12 \%$, Quality, quantity and how much $3.09 \%$, As well as the quantity, quality and relevance as $1.09 \%$, Speech Prabowo national political figures are also in violation of the four maxims are: maxim of quantity, maxim of quality, relevance and maxims maskism how much $4.12 \%$, That is, the speech of national political figures more dominant Prabowo comply with the principles of cooperation of 97 data, it can comply with the detailed speech $52(53.61 \%)$, and breaking the 45 utterances $(46.39 \%)$. This result suggests that the use of the principles of cooperation of national political figures Prabowo included in language assessment criteria "less". From the details of the table above, the use of speech politeness principle in national political figure Prabowo more memetahui dibandingka with abuse. It can be concluded that the communication made by national political figures during a speech Prabowo adhere to the principle of politeness.

According Luthfiyanti $(2017$, p.15) states that the speech was polite when showing six things: (1) wisdom maxims, maxims have this linguistic politeness principle is that participants should utterances should always adhered to the principle to continuously reduce the profits for themselves and maximize the benefit to the other party in the activities bertutur; (2) Is also called the generosity maxim maxim of acceptance. This maxim requires each participant to maximize the speech acts themselves and minimize losses profits for themselves. This maxim is expressed by speech commissive and imposif; (3)maxim of praise is a maxim that uses speech by reducing insults at others and add to the praise on others. In the award maxims explained that a person would be considered polite when in speaking always reward hearer; (4)maxim maxim of simplicity or also called humility, with this maxim speakers are expected to keep a low profile by reducing the praise of himself. Maksim is also expressed by the utterances expressive and assertive. When the generosity maxim centered on others, this maxim humility self-centered; (5)said participants stressed the maxim agreement to establish a match in activities bertutur; and (6)sympathy maxim requires participants said maximize sympathy between the parties with each other.

National political figures of speech that memetahui Prabowo single politeness principle is: adhere to the maxim of wisdom, generosity maxims, maxims of praise, humility maxims, maxims agreement and sympathy maxim. Utterances national political figures who abide prisnsip Prabowo double politeness namely: the maxim of generosity with praise maxims, maxims generosity with sympathy maxims, maxims generosity with sympathy maxims, maxims maxims generosity with modesty and humility with maxims maxims sympathy.

National political figures Prabowo when there are political speeches comply seen maxims wisdom of efforts to reduce profits for themselves and maximize the benefit to the other party. Efforts to provide benefits for others done to deliver the vision and political missions. National 
political figures Pabowo speech that adhere to the maxim of wisdom Subianto can be seen in the following example.

(1) Kami juga akan pastikan, perusahaan-perusahaan BUMN penting kita, seperti Krakatau Steel, Pertamina dan Garuda kuat dan tidak terus menerus rugi. (P5PS48)

Speech (1) speakers adhere to the maxim of wisdom because tuturannya sendri minimize the benefits to themselves and maximize profits for others. In the above speechthe context of the speech occurs when the body's office inauguration speech pemengan dikegiatan Prabowo Password hosted by the award body region (BPD) in Boyolali, Central Java, Central Java. Speakers adhere to the maxim of wisdom, it is evident from the statement "perusahaanperusahaan BUMN penting kita, seperti Krakatau Steel, Pertamina dan Garuda kuat dan tidak terus menerus rugi". In this case, the speaker would like to have been of certainty to state companies in order to not lose money.

National political figures Prabowo when there are political speeches comply generosity maxim visible from addressing respect for others as well as reducing the benefits for themselves and maximize profits for others. Respect for others is done by national political figures Prabowo form of respect. Speech Prabowo national political figures who adhere to the maxim of generosity can be seen in the following example.

(2) Apapun keputusan rakyat kami terima, kami hormat, kami hanya ingin berkuasa dengan izin rakyat, dan kami ingin berkuasa untuk mengabdi kepada rakyat Indonesia. Kami ingin mengabdi supaya tidak ada orang miskin di Indonesia, dan tidak boleh ada orang lapar di Indonesia, tidak boleh ada keadilan tidak sampai ke seluruh rakyat Indonesia. Saya kira itu tekad kami, itu hasrat kami. (P2-PS22)

Speech (2) speakers adhere to the maxim of generosity for tuturannya maximize losses for herself. Context speech occurs at the time of the declaration of the presidency and vicepresident of the Republic of Indonesia in the General Election Commission, Central Jakarta. Speakers adhere to the maxim of generosity, it is evident from the statement "Kami ingin mengabdi supaya tidak ada orang miskin di Indonesia, dan tidak boleh ada orang lapar di Indonesia, tidak boleh ada keadilan tidak sampai ke seluruh rakyat Indonesia. Saya kira itu tekad kami, itu hasrat kami". The phrase "saya kira itu tekad kami, itu hasrat kami" is a form of speech maximize losses for herself.

National political figures Prabowo when political speech are visible adhere praise maxims of efforts to reduce criticism on others and add to the praise on others. Praise deberikan by national political figure Prabowo to another party a sense of admiration for the achievement of something. National political figures of speech that adhere to the maxim of praise can be seen in the following example.

(3) Partai Demokrat yang telah melahirkan seorang Presiden Republik Indonesia, yang telah memimpin bangsa Indonesia 10 tahun dengan adem ayem, dengan tenang, dengan sejuk, dengan stabilitas dan tentunya Partai Gerakan Indonesia Raya, partai saya sendiri. (P4-PS29)

Speech (3) speakers adhere to the maxim of praise, speakers maximize perghargaan against others. Context utterances occurs during a speech nationality "Indonesia Win" in Jakarta. Speakers adhere to the maxim of praise, it is evident from the statement "Partai Demokrat yang telah melahirkan seorang Presiden Republik Indonesia, yang telah memimpin bangsa Indonesia 10 tahun dengan adem ayem, dengan tenang, dengan sejuk, dengan stabilitas" The sentence intends praised the democratic party who has given birth to a president of the Republic of Indonesia led by the cool and calm. 
National political figures Prabowo when there are political speeches comply modesty maxim visible effort to be humble by reducing the praise of himself. Humble attitude made by national political figures Prabowo is aware of the limitations attitude of her abilities. Speech Prabowo national political figures who memathi maxim of humility can be seen in the following example.

(4) Saudara-saudara sekalian, gunakanlah, saya Prabowo Subianto adalah alat kalian. Gunakan saya sebagai alatmu, saudara-saudara sekalian. Bagi saya, kehormatan yang paling mulia digunakan sebagai alat bagi bangsa dan rakyat saya. (P1-PS18)

Speech (8) speakers adhere to the maxim of humility by minimizing respect for yourself and maximize respect for others. Context speech occurs when dikegiatan deklarsi welcome the support of the Indonesian Trade Union Confederation (KSPI) in Senayan, Jakarta. Speakers adhere to the maxim of humility, it is evident from the statement "Bagi saya, kehormatan yang paling mulia digunakan sebagai alat bagi bangsa dan rakyat saya" speakers offer herself as a tool for the benefit of the nation.

National political figures Prabowo when there are political speeches comply seen maxim deal of effort to reduce the mismatch on yourself with others and improve persesuain between oneself and others. Incompatibility yourself done by national political figures are what the business can provide a certain party approval. Speech Prabowo national political figures who adhere to the maxim of the agreement can be seen in the following example.

(5) Dalam tuntutan itu, saudara-saudara minta transportasi umum murah. Betul? Saya lihat di negara tetangga kita, sudah lebih 10 tahun, 15 tahun bukan transportasi murah, tapi di Thailand, transportasi itu bagi rakyat miskin tidak bayar. Kalau mereka bisa, kenapa kita tidak bisa. Kalau mereka mampu membela rakyatnya, kenapa bangsa Indonesia tidak mampu membela rakyatnya? (P1-PS12)

Speech (9) speakers adhere to the maxim of the deal, because the speaker said something prioritize adjustments between oneself and others so that what is presented to provide specific and informed consent. Context speech occurs when dikegiatan deklarsi welcome the support of the Indonesian Trade Union Confederation (KSPI) in Senayan, Jakarta. Speakers adhere to the maxim of the agreement, it is evident from the statement "kalau mereka bisa, kenapa kita tidak bisa. Kalau mereka mampu membela rakyatnya, kenapa bangsa Indonesia tidak mampu membela rakyatnya?" speakers are not trying to deduce what dituturkannya unilaterally. Speakers invited to able to defend the people.

National political figures Prabowo when political speech are visible adhere sympathy maxim of efforts to reduce the antipathy between oneself and others and increase sympathy between oneself and others. Sympathetic to others carried out by a national political figure Prabowo is an expression of caring to others. Speech Prabowo national political figures who adhere to the maxim of sympathy can be seen in the following example.

(6) Beberapa waktu yang lalu, saya mendapat laporan, seorang buruh tani, seorang bapak, bernama pak Hardi di Desa Tawangharjo, Grobokan, meninggal dunia karena gantung diri di pohon jati di belakang rumahnya. Almarhum gantung diri, meninggalkan isteri dan anak karena merasa tidak sanggup membayar utang, karena beban ekonomi yang ia pikul dirasa terlalu berat. (P5-PS36)

Speech (6) speakers adhere to the maxim of sympathy to maximize the sense of caring for others. KContext utterances occurs during a speech dikegiatan Gerindra Party conference in Jakarta. Speakers adhere to the maxim of sympathy, it is evident from the statement "Beberapa waktu yang lalu, saya mendapat laporan, seorang buruh tani, seorang bapak, 
bernama pak Hardi di Desa Tawangharjo, Grobokan, meninggal dunia karena gantung diri di pohon jati di belakang rumahnya" sentence speakers expressed invited to give a sense of caring to a worker who died of suicide by self hinge behind the house.

National political figures Prabowo when political speech there abide and adhere to the maxim maxim praise generosity visible from addressing respect for others and reduce criticism on others and add to the praise on others. Respect for others is done by national political figures Prabowo menghagai form of flavor. Praise to others is awe speakers to the achievement of something. Speech Prabowo national political figures who adhere to the maxim of generosity and memathui maxim of praise can be seen in the following example.

(7) Saya juga didampingi oleh tokoh Jawa Tengah dan tokoh TNI yaitu mantan Gubernur Jawa Tengah Letnan Jenderal TNI Purnawirawan H Bibit Waluyo. Saudara-saudara di Jawa Tengah yang lebih tahu bagaimana seorang Bibit Waluyo itu. Orang gubernur yang bekerja keras untuk rakyat, untuk petani, untuk nelayan, untuk wong cilik di seluruh Jawa Tengah. (P4-PS33)

Speech (7) in honor of a prominent speaker and pay tribute to the person concerned. Context utterances occurs during a speech nationality "Indonesia Win" in Jakarta. Speakers adhere to the maxim of generosity by the maxims of praise, it is seen in the speech, "Saudarasaudara di Jawa Tengah yang lebih tahu bagaimana seorang Bibit Waluyo itu. Orang gubernur yang bekerja keras untuk rakyat, untuk petani, untuk nelayan, untuk wong cilik di seluruh Jawa Tengah", speakers in honor of a former governor of Central Java. Speakers also gave awards terhadpa performance of the former governor of Central Java.

National political figures Prabowo when political speech there abide and adhere to the maxim maxim generosity humility, visible from addressing respect for others and humility by reducing the praise of himself .. Respect for others is done by national political figures Prabowo menghagai form of flavor. Humble attitude made by national political figures Prabowo is aware of the limitations attitude of her abilities. Speech Prabowo national political figures who adhere to the maxim of generosity and humility memathui maxims can be seen in the following example.

(8) Namun di sini saya sampaikan. Jika saya dipilih bersama Sandiaga, saya akan bekerja untuk seluruh rakyat Indonesia, termasuk untuk saudara yang belum percaya kepada kami. (P6-PS66)

Speech (8) speakers have been of respect for others and reduce compliment to ourselves. Context speech occurs when the body's office inauguration speech pemengan dikegiatan Prabowo Password hosted by the award body region (BPD) in Boyolali, Central Java, Central Java. Speakers comply with the maxim maxim kedermawnan humility, it is evident from the statement "saya akan bekerja untuk seluruh rakyat Indonesia, termasuk untuk saudara yang belum percaya kepada kami", the speaker gave respect terdapap people who do not believe him. Speakers also submit himself to work for the people of Indonesia.

National political figures Prabowo when political speech there abide and adhere to the maxim maxim of generosity visible deal of effort to provide respect for others as well as efforts to reduce the mismatch on yourself with others and improve persesuain between oneself and others. Respect for others is done by national political figures Prabowo menghagai form of flavor. Incompatibility yourself done by national political figures are what the business can provide a certain party approval. Speech Prabowo national political figures who adhere to the maxim of generosity and memathui maxim of the deal can be seen in the following example.

(9) Terima kasih kepada semua pihak mengikuti perkembangan dari semua elemen agama, semua etnis, semua ras, semua suku, kita berjuang untuk NKRI, untuk Indonesia. Kita 
bejuang untuk seluruh rakyat Indonesia apapun sukunya, kelompok etnisnya, kelompok agamanya, apapun rasnya, seluruh warga Indonesia, rakyat kita, akan kita bela akan kita perjuangkan hak-haknya. (P2-PS21)

Speech (9) speakers pay tribute to a particular party and speakers menyatakankan something that not too much so that what is presented to provide specific and informed consent. Context speech occurs at the time of the declaration of the presidency and vicepresident of the Republic of Indonesia in the General Election Commission, Central Jakarta. Speakers adhere to the maxim of generosity with maxims kesepaktan, it is evident from the statement "Kita bejuang untuk seluruh rakyat Indonesia apapun sukunya, kelompok etnisnya, kelompok agamanya, apapun rasnya, seluruh warga Indonesia, rakyat kita, akan kita bela akan kita perjuangkan hak-haknya" speakers provide penghagaan to the people who are struggling to defend their rights. Speakers also not trying to conclude unilaterally what is spoken.

National political figures Prabowo when political speech there abide and adhere to the maxim maxim of generosity visible deal of effort to give respect to others and reduce the antipathy between oneself and others and increase sympathy between oneself and others. Respect for others is done by national political figures Prabowo menghagai form of flavor. Sympathetic to others carried out by a national political figure Prabowo is expressing care for others. Speech Prabowo national political figures who adhere to the maxim of generosity and sympathy maxim can be seen in the following example.

(10) Ada satu kejadian unik pada hari ini ada putri presiden pertama RI, putri proklamator kita, ada juga putri presiden RI yang kedua, ada juga dua putra presiden RI yang keenam. Saudara-saudara, ini kehormatan besar bagi saya. Saya ingin mengucapkan terima kasih ke KPU yang bekerja keras. (P3-PS21)

Speech (10) speakers maximize damages for himself and sympathy for something to happen. Context utterances occurs during a political speech dikegiatan Grand Reunion 212, Jakarta. Speakers comply with maxims ksimpatian generosity maxim, it is evident from the statement "Saudara-saudara, ini kehormatan besar bagi saya. Saya ingin mengucapkan terima kasih ke KPU yang bekerja keras", the speaker thanked atak hard work of election commissions.

National political figures Prabowo when there are political speeches comply maxim maxim of humility and sympathy visible effort to be humble by reducing the praise of itself and reduce the antipathy between oneself and others and increase sympathy between oneself and others. Humble attitude made by national political figures Prabowo is aware of the limitations attitude of her abilities. Respect for others is done by national political figures Prabowo menghagai form of flavor. Sympathetic to others carried out by a national political figure Prabowo is expressing care for others.

(11) Dari sejak umur 18 tahun saya sudah mempertaruhkan jiwa dan raga saya demi RI yang kita cintai. Dengan tekad dan dengan harapan hati saya bahwa kami para prajurit akan menjaga negara dan kaum pemimpin, kaum cendekiawan, kaum elite sipil akan mengelola dan memimpin negara sebaik-baiknya agar rakyat kita sejahtera, rakyat kita makmur, rakyat kita mengalami kehidupan yang adil dan sejahtera. (P1-PS2)

Speech (11) speakers minimizing respect for yourself and maximize respect for others, in addition to the speakers provide a sense of sympathy toward others. Context speech occurs when dikegiatan deklarsi welcome the support of the Indonesian Trade Union Confederation (KSPI) in Senayan, Jakarta. Speakers adhere to the maxim of humility with the maxims of sympathy, it is evident from the statement "kami para prajurit akan menjaga negara dan 
kaum pemimpin, kaum cendekiawan, kaum elite sipil akan mengelola dan memimpin negara sebaik-baiknya agar rakyat kita sejahtera, rakyat kita makmur, rakyat kita mengalami kehidupan yang adil dan sejahtera". Speakers have a strong belief against the soldiers who will keep the country and the leader. Speakers also put sympathy to the people in order to get a fair and prosperous life.

Utterances national political figure Prabowo also a speech that violates the principle of a single politeness namely: abuse generosity maxim, maxim of praise, humility maxims, maxims and maxims deal of sympathy. National political figures are Prabowo also violates the principle of double politeness namely: violating the maxim of wisdom and sympathy maxims, maxims of humility and praise and maxim maxim maxim agreement and sympathy. Violations of politeness principle national political figure Prabowo described as follows.

National political figures Prabowo when there is political speech violates the maxim of generosity visible from maximizing profits for himself and minimize profits for others. Maximizing profits for themselves dialukan by national political figures Prabowo Subanto for support in his political career. National political figures Prabowo speech Subiantoyang violate the maxim of generosity can be seen in the following example.

(12) Tetapi bisa juga karena mereka tidak mampu, tidak mampu melihat kepentingan rakyat Indonesia, tidak mampu menjaga kepentingan bangsa dan rakyat Indonesia. Tidak mampu menjaga kekayaan bangsa $01 \mathrm{Mei} 2018$ Indonesia. Karena itu saya memutuskan kepada diri saya sendiri. Bahwa apabila rakyat saya masih membutuhkan saya, apabila rakyat saya masih ingin memakai tenaga, jiwa dan raganya Prabowo Subianto, maka saya siap melaksanakan tugas. (P1-PS4)

Speech (12) speakers seen violating the maxim of generosity for maximizing profits for himself. Context speech occurs when dikegiatan deklarsi welcome the support of the Indonesian Trade Union Confederation (KSPI) in Senayan, Jakarta. Speakers violate the maxim of generosity, it is evident from the statement "Bahwa apabila rakyat saya masih membutuhkan saya, apabila rakyat saya masih ingin memakai tenaga, jiwa dan raganya Prabowo Subianto, maka saya siap melaksanakan tugas" The speaker asks to be given the opportunity of people when they require tanaganya, which would indirectly benefit from the speakers of the speech.

National political figures Prabowo when political speech violates the maxim of praise are visible effort to give a compliment to someone else, but insinuated parties. Praise deberikan by national political figure Prabowo to another party a sense of admiration for the achievement of anything but praise is accompanied by allusions to other parties. National political figures of speech that violates the maxim of praise can be seen in the following example.

(13) Singa-singa tua yang turun dari gunung untuk membela negara dan bangsa kita walaupun mereka mungkin giginya sudah ompong. Giginya ompong semangatnya masih menyala, tapi terutama yang saya rasakan adalah dukungan dari emakemak yang militan. Emak-emak ini militan. Mereka berani. (P4-PS30)

Speech (13) is a national political figure of speech that violates the maxim Prabowo praise, give praise but marginalize one of which is praised. the context of the speech occurs at the time of the speech nationality "Indonesia Win" in Jakarta. It is seen in the phrase "mereka mungkin giginya sudah ompong. Giginya ompong semangatnya masih menyala, tapi terutama yang saya rasakan adalah dukungan dari emak-emak yang militan. Emak-emak ini militan”, Speakers giving out compliments However the next corner the party is not stronger spirit of mothers militant and bolder on the fathers.

National political figures Prabowo when there is political speech violates the maxim of humility seen from the attitude of speakers who are not humble to praise himself. Humble 
attitude is not done by a national political figure Prabowo is a narrative to believe that he was right. Speech Prabowo national political figures who violate the maxim of humility can be seen in the following example.

(14) Saya sudah buktikan tahun 2014 sebetulnya pihak kami merasa diperlakukan dengan tidak benar. Hakim-hakim MK tidak mau buka bukti-bukti yang kami bawa. Tapi kami mengalah kami terima bahkan saya tuturanng pada pelantikan lawan saya. Ada yang enggak pernah tuturanng kalau lawannya dilantik. Kasih tangan aja enggak mau. (P6-PS91)

In the speech (14) looks speakers violates the maxim of humility, speakers look too much credit to himself. Context utterances occurs during a speech dikegiatan Gerindra Party conference in Jakarta. Speakers violate the maxim of humility, it is evident from the statement "kami mengalah kami terima bahkan saya tuturanng pada pelantikan lawan saya", Speakers too far in praising himself. Speakers stated that he tuturanng inauguration political opponents, when he lost the presidential election arena.

National political figures Prabowo when there is political speech violates the maxim of the agreement unilaterally evident from the speakers concluded something to waive noncompliance with other parties. Summing unilaterally and disregard incompatibility with other people is forcing listeners to agree with the speaker's speech. Speech Prabowo national political figures who violate the maxim of the agreement can be seen in the following example.

(15) Dan bila nanti insyaallah kita berhasil, saya yakin dengan cepat kita akan rubah keadaan bangsa Indonesia. Karena apa? Saya sudah punya tuturan dan saya sudah bikin buku dan saya sudah sebarkan belasan tahun. dan saya mengatakan bahwa kekayaan Indonesia dirampok, dicuri. (P1-PS8)

Speech (15) speakers seen violating the maxim deal, because the speaker unilaterally conclude something to waive non-compliance with other parties. Context speech occurs when dikegiatan deklarsi welcome the support of the Indonesian Trade Union Confederation (KSPI) in Senayan, Jakarta. Speakers violate the maxim of the agreement, it is evident from the statement "kita berhasil, saya yakin dengan cepat kita akan rubah keadaan bangsa Indonesia",The speaker considers there are still many problems in the country of Indonesia that has not been resolved. Speakers too far in expressing his opinion and unilaterally conclude anything without thinking about whether this opinion is approved or not by certain parties.

National political figures Prabowo when political speech violates the maxim of sympathy are visible from the speakers who have sympathy but with allusions to other parties. Sympathy with sarcasm merungikan particular party. Speech Prabowo national political figures who violate the maxim of sympathy can be seen in the following example.

(16) Ternyata di saat saya harus pensiun, di saat saya harus istirahat, saya melihat negara saya berada dalam keadaan yang tidak adil dan tidak makmur. Saya melihat elite-elite Indonesia, entah bodoh atau entah apa, atau memang mereka hatinya sudah beku, atau memang mereka tidak cinta sama bangsa Indonesia. (P1-PS3)

Speech (16) speakers seen violating the maxim of sympathy, because the speaker showed sympathy toward others as he threw a sentence in the form of satire. KContext speech occurs when dikegiatan deklarsi welcome the support of the Indonesian Trade Union Confederation (KSPI) in Senayan, Jakarta. Speakers violate the maxim of sympathy, it is evident from the statement "saya melihat negara saya berada dalam keadaan yang tidak adil dan tidak makmur. Saya melihat elite-elite Indonesia, entah bodoh atau entah apa, atau memang mereka hatinya sudah beku, atau memang mereka tidak cinta sama bangsa Indonesia" 
penutur stated ketidaksimpatian with the parties in question, because the expression is indirectly insinuated leaders who have not been able to create a state within a state fair and prosperous. Moreover, to call "Indonesian elites, either stupid or something, or indeed their heart is frozen, or if they do not love each nation Indonesia"Which can be interpreted as permasalahn already berkepanjang that can not be resolved.

National political figures Prabowo when there is political speech violates the maxim of wisdom and sympathy maxim visible from the speakers to maximize profits for itself and not sympathy for the events dituturkannya. The advantage for himself carried by speakers to mendaatkan empathy and sympathy for the speaker nor spoken events. Speech Prabowo national political figures who violate the maxim of wisdom and sympathy can be seen in the following example. ,

(17) Tetapi bisa juga karena mereka tidak mampu, tidak mampu melihat kepentingan rakyat Indonesia, tidak mampu menjaga kepentingan bangsa dan rakyat Indonesia. Tidak mampu menjaga kekayaan bangsaIndonesia. Karena itu saya memutuskan kepada diri saya sendiri. Bahwa apabila rakyat saya masih membutuhkan saya, apabila rakyat saya masih ingin memakai tenaga, jiwa dan raganya Prabowo Subianto, maka saya siap melaksanakan tugas. (P1-PS4)

Speech (17) the context of the speech occurs when the body's office inauguration speech pemengan dikegiatan Prabowo Password hosted by the award body region (BPD) in Boyolali, Central Java, Central Java. Speakers maximize profits for themselves and not sympathy for the events dituturkannya. Speakers violate the maxim of wisdom and keseimpatian, it looks at the statement "saya memutuskan kepada diri saya sendiri. Bahwa apabila rakyat saya masih membutuhkan saya, apabila rakyat saya masih ingin memakai tenaga, jiwa dan raganya Prabowo Subianto, maka saya siap melaksanakan tugas" speaker intends to be given the opportunity of people when they require tanaganya, which would indirectly speakers benefit from speech the. speakers no sympathy for the country was bearing debt.

National political figures Prabowo when there is political speech violates the maxim maxim of humility and praise can be seen from speakers Excessive praise himself and honor to himself, Speech Prabowo national political figures who violate the maxim maxim of humility and praise can be seen in the following example.

(18) Dalam usia saya yang sekarang 67 tahun, saya sudah mengabdi pada negara dan bangsa di berbagai bidang terutama sejak umur 18 tahun. Saya berjuang, mengabdi sebagai seorang prajurit, TNI. Sejak usia muda saya telah menandatangani bahwa suatu perjanjian dengan negara bahwa saya siap untuk berkorban jiwa dan raga untuk membela kemerdekaan, kedaulatan dan kejayaan bangsa Indonesia. (P1-PS1)

Speech (19) speakers excessive praise himself and pay tribute to himself. Context speech occurs when dikegiatan deklarsi welcome the support of the Indonesian Trade Union Confederation (KSPI) in Senayan, Jakarta. Speakers violate the maximhumility with maxims of praise, it is evident from the statement " saya sudah mengabdi pada negara dan bangsa di berbagai bidang terutama sejak umur 18 tahun. Saya berjuang, mengabdi sebagai seorang prajurit, TNI" The speech shows that the speakers too far in praising himself and pay tribute to himself. Speakers stated that he was devoted to the state has been started since the age of 18 years.

National political figures Prabowo when addressing politics are violating the maxim of humility and maxims praise, visible from the speakers unilaterally conclude something and speakers are not sympathetic to the other side of utterances national political figures Prabowo 
who violate the maxim of the agreement and the maxim of sympathy can be seen in the following example.

(19) Saudara-saudara sekalian, kekayaan Indonesia tidak tinggal di Indonesia. Kita adalah negara yang paling... ada wartawan nggak? Ya sudah terserah mau dipelintir bagaimana, nggak ada urusan sama gue. (P1-PS9)

Speech (19) unilaterally speakers and the speakers did not conclude anything sympathy toward others. KContext speech occurs when dikegiatan deklarsi welcome the support of the Indonesian Trade Union Confederation (KSPI) in Senayan, Jakarta. Speakers violating an agreement with the maxim maxim of sympathy, it looks at the speech "Saudara-saudara sekalian, kekayaan Indonesia tidak tinggal di Indonesia" of this speech can be concluded that the speaker considers the wealth of Indonesia did not stay in indonesia. Speakers too far in expressing his opinion and unilaterally conclude anything without thinking about whether this opinion is approved or not by certain parties. Speakers also no sympathy for the situation.

\subsection{Discussion}

The results of the analysis of utterances national political figures contained Prabowo keep and violates the maxim and the two maxims of politeness principle. Speech that adhere to the maxim of politeness principle, namely: the maxim of wisdom as much as $15.46 \%$, the maxim of generosity as much as $4.12 \%, 3.09 \%$ praise maxims, maxims of humility as much as $8.24 \%$, the maxim of the deal as much as $15.46 \%$, and maxim of sympathy as much as $4.12, \%$. Speech that adhere to the two maxims of politeness principle, namely: the generosity maxim pijian as much as $2.06 \%$, the generosity with humility as much as $1.03 \%$, the generosity of the deal as much as $2.06 \%$, generosity and sympathy as much as $2.06 \%$, humility with sympathy as much as $1.03 \%$ and the agreement with sympathy as much as $1.03 \%$. Speech that violates the maxim of politeness principle, namely: the maxim of generosity as much as $2.06 \%$, maxim praise as much as $1.03 \%$, the maxim of humility as much as $1.03 \%$, the maxim of the deal as much as $19.58 \%$, and the maxim of sympathy as much as $9.28 \%$. Utterances that violate the two maxims of politeness principle, namely: the maxim of wisdom with sympathy as much as $1.03 \%$, the praise with humility as much as $2.06 \%$ and kesepakatang with sympathy as much as $3.09 \%$. That is, the speech of national political figures more dominant Prabowo adhere to the principle of politeness, of 97 data adhere to as much as 57 utterances $(58.72 \%$ ) and in violation of 40 utterances $(41.28 \%)$. These results indicate the use of communication politeness principle national political figure Prabowo included in the language of assessment criteria of "good enough". Utterances that violate the two maxims of politeness principle, namely: the maxim of wisdom with sympathy as much as $1.03 \%$, the praise with humility as much as $2.06 \%$ and kesepakatang with sympathy as much as $3.09 \%$. That is, the speech of national political figures more dominant Prabowo adhere to the principle of politeness, of 97 data adhere to as much as 57 utterances $(58.72 \%)$ and in violation of 40 utterances $(41.28 \%)$. These results indicate the use of communication politeness principle national political figure Prabowo included in the language of assessment criteria of "good enough". Utterances that violate the two maxims of politeness principle, namely: the maxim of wisdom with sympathy as much as $1.03 \%$, the praise with humility as much as $2.06 \%$ and kesepakatang with sympathy as much as $3.09 \%$. That is, the speech of national political figures more dominant Prabowo adhere to the principle of politeness, of 97 data adhere to as much as 57 utterances $(58.72 \%)$ and in violation of 40 utterances $(41.28 \%)$. These results indicate the use of communication politeness principle national political figure Prabowo included in the language of assessment criteria of "good enough". national political figures of speech more dominant Prabowo adhere to the principle of politeness, of 97 data adhere to as much as 57 utterances 
$(58.72 \%)$ and in violation of 40 utterances $(41.28 \%)$. These results indicate the use of communication politeness principle national political figure Prabowo included in the language of assessment criteria of "good enough". national political figures of speech more dominant Prabowo adhere to the principle of politeness, of 97 data adhere to as much as 57 utterances $(58.72 \%)$ and in violation of 40 utterances $(41.28 \%)$. These results indicate the use of communication politeness principle national political figure Prabowo included in the language of assessment criteria of "good enough".

The results of this study differs from other studies with Dramatugi Analysis Speech of President Susilo Bambang Yudhoyono on Bintan Island Aquatic diseputar incident whose findings use politeness principle of President Susilo Bambang Yudhoyono more dominant adhere to the maxim. 1 september 2010 speeches held at the headquarters of Indonesian National Armed Forces related to inseden Bintan island claimed by neighboring Malaysia [22]. This finding contrasts influenced political positions and attitudes, Susilo Bambang Yudhoyono gave a speech as President of the firm and dampen the anger of the people of Indonesia to neighboring countries, while the position and attitude of different political Prabowo with Susilo Bambang Yudhoyono although both preside over a party. Positions to be one factor in the use of the principle of politeness,

\section{Conclusion}

Application of the principle of politeness by national political figures Prabowo includes maxims of wisdom, generosity maxims, maxims of praise, humility maxims, maxims and maxims deal of sympathy. This shows that national political figures speech Prabowo can be quite polite and relevant to the opinion of Leech (1986) that in order to create a language that courtesy then must pay attention to the six principles of politeness. The use of communication politeness principle national political figure Prabowo based criteria [24] The language assessment showed "good enough".

\section{References}

[1] Zahid, M.: Politeness in Indonesia Lawyers Club Debate on TV One First Semester 2015, in the Journal of PendidikanVol.2.No. 3, pp, 20-21. (2015)

[2] Asmara, R.: President Jokowi's lingguistic strattegy insistilling govermmen ideology and manifesto. Litera, Vol 15, pp. 379-388 (2016)

[3] Arofah K.: Youtube as media clarification and statements of political figures. Journal of comunicationscience, Vol. 13, pp.111-123. (2015)

[4] Widyarwati: Representation of this ideology in the compassionof state speech at eye najwa talk show. Seloka, Vol 5, pp.1-1. (2016)

[5] Ermanto, Agustina and Emidar.: Politeness Communications of Official in West Sumatra: Riview of Principeles of Politenessand Principles of COOPRATION Perspective, Joernal Atlantis Communications, Vol 263, pp.315-319. (2018).

[6] Culpeper, J.: impoliteness revisited: with special reference to dynamic and prosidie aspects, Journal of pragmatic, Vol. 35, No. 10, pp. 12-13. (2003)

[7] Jansen, F.: Efreits of positive politeness strategy in business letters, Journal of pragmatic, Vol. 36, No. 11, pp. 6-7. (2004)

[8] Rudanko, J.: aggravated impoliteness and two types of speaker intention in an episode in shakespear as Timon of Athens, The Journal of pragmatic, Vol. 38, No. 6, pp, 20-24. (2006) 
[9] Noulizavin, P.: Rong in television political debates, Journal of pragmatic, Vol. 43, No. 2, pp, 35-36. (2011)

[10] Wacker, M .: That is your evidence? Classifying stance in online political debate, pragmatic Journal, Vol. 10, No. 13, pp, 12-16. (2011)

[11] Grebelsky, T.: The role of verbal and nonverbal behaviuor televised political debates, published online Journal, Vol. 10, No. 15, pp. 16-17. (2014)

[12] Fracchiola, B.: Politeness as a strategy of attack in a gendered political debate-the royal-Sarkozy debate, Journal of pragmatic, Vol. 10, No. 2, pp. (2011)

[13] Yuni .: Violation Courtesy Speak In Political Communication In the South Sulawesi gubernatorial election of 2013. PPS Gajah Mada University. (2013)

[14] Solemmanni, H.: An analysis of pragmatics competence in the 2013 presidential election candidates of Iran: a comparison of speech acts with the peel outcomes, publication academy Journal, Vol. 6, No. 4, pp, 12-15. (2006)

[15] Bravo, D.: Politenessin Spanish speaking Socio-Cultural Contexts: introductions, associations pragmatic Journal, Vol. 18, No. 4, pp. 8-9. (2008).

[16] Smith, S.: honorifics Politeness an Japaness power in political, pragmatic Journal, Vol. 10, No. 6, pp, 12-16. (2011)

[17] Dicket, C.: Formal verbal forms strategic er? Politeness theory and Japaness business etiquette training, pragmatic Journal, Vol. 10, No. 10, pp. 5-6. (2011).

[18] Yerhin, N.: A pragmatics analysis of derogration in the discourse of political criticism in the Turkish grand national assembly, faculty Journal, Vol. 2, No. 10, pp, 35-36. (2015)

[19] Joseph, C.: The use of demonstrative and context activation in catalan parliamentary debate, pragmatic Journal, Vol. 10, No. 16, pp. 27-28. (2011)

[20] Leech, Geoffrey.: Principles of pragmatics. Jakarta: UI Press. (1983)

[21] Ratna, N K.: Theory, methods, and techniques of language study. (Yogyakarta: Student Reader (2008)

[22] Kutubi.: Analysis Dramatugi Speech of President Susilo Yudhoyono About Incident Bodies threshold Bintan Island in Society \& Culture Journal, Vol.13 \# 1 pp. 15-21. (2011)

[23] Brown, P and SC Levinson.: Universal in Language Usage: Politeness Fhenomena.In EN (ed). Questionand Politeness Strategies in Social Interaction.Cambridge: Cambridge Universitis Press. (1987)

[24] Abdurahman and Ellya Ratna.: Evaluation of Learning Indonesian. Padang: UNP Press. (2003) 